Prepared in cooperation with the

Connecticut Department of Energy and Environmental Protection

\title{
Nitrogen Loads from Selected Rivers in the Long Island Sound Basin, 2005-13, Connecticut and Massachusetts
}

Open-File Report 2016-1007

U.S. Department of the Interior U.S. Geological Survey 



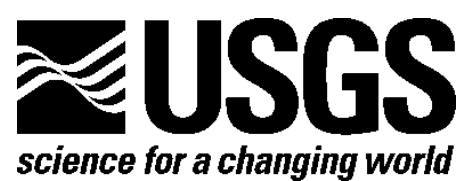

Prepared in cooperation with the Connecticut Department of Energy and Environmental Protection

\section{Nitrogen Loads from Selected Rivers in the Long Island Sound Basin, 2005-13, Connecticut and Massachusetts}

By John R. Mullaney

Open-File Report 2016-1007

U.S. Department of the Interior

U.S. Geological Survey 


\section{U.S. Department of the Interior \\ SALLY JEWELL, Secretary}

\section{U.S. Geological Survey \\ Suzette M. Kimball, Director}

U.S. Geological Survey, Reston, Virginia: 2016

For more information on the USGS-the Federal source for science about the Earth, its natural and living resources, natural hazards, and the environment-visit http://www.usgs.gov/ or call 1-888-ASK-USGS (1-888-275-8747).

For an overview of USGS information products, including maps, imagery, and publications, visit http://www.usgs.gov/pubprod/.

Any use of trade, firm, or product names is for descriptive purposes only and does not imply endorsement by the U.S. Government.

Although this information product, for the most part, is in the public domain, it also may contain copyrighted materials as noted in the text. Permission to reproduce copyrighted items must be secured from the copyright owner.

Suggested citation:

Mullaney, J.R., 2016, Nitrogen loads from selected rivers in the Long Island Sound Basin, 2005-13, Connecticut and Massachusetts: U.S. Geological Survey Open-File Report 2016-1007, 14 p., http://dx.doi.org/10.3133/ofr20161007.

ISSN 2331-1258 (online) 


\section{Contents}

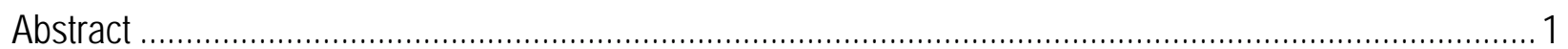

Introduction

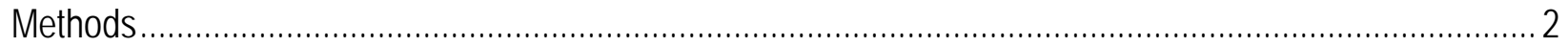

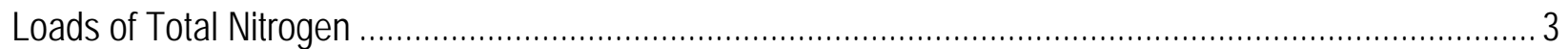

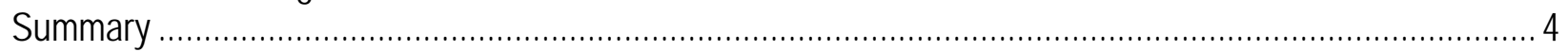

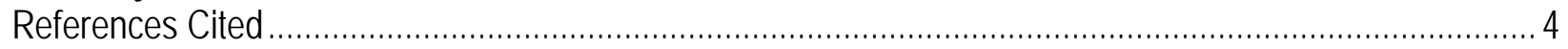

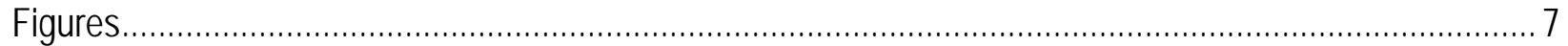

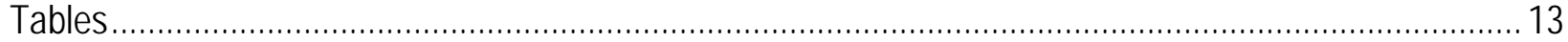

Appendix 1. LOADEST Regression Equations Used To Estimate Annual Loads of Total Nitrogen From

Selected Rivers in the Long Island Sound Basin, 2005-13, Connecticut and Massachusetts..................... 14

\section{Figures}

1. Map showing selected water-quality monitoring and streamflow-gaging stations, Long Island Sound

Basin, Connecticut and Massachusetts

2. Graphs showing the total nitrogen load estimate and limit of the 95-percent confidence interval for

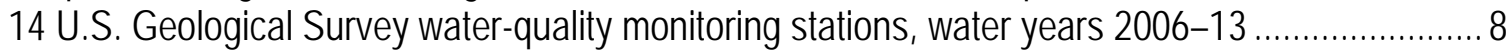

3. Boxplots showing total nitrogen yield for U.S. Geological Survey water-quality monitoring stations in the Long Island Sound Basin, Connecticut and Massachusetts, water years 2006-13 .............. 12

\section{Tables}

1. Water-quality monitoring stations used for nitrogen load analysis from rivers draining to Long Island Sound Basin.....

2. Total nitrogen load and yield and selected regression model and flux-bias diagnostics for each water-quality monitoring station, Long Island Sound Basin, water years 2006-13 


\section{Conversion Factors}

Inch/Pound to International System of Units

\begin{tabular}{lcl}
\hline \multicolumn{1}{c}{ Multiply } & By & \multicolumn{1}{c}{ To obtain } \\
\hline \multicolumn{3}{c}{ Length } \\
\hline mile $(\mathrm{mi})$ & 1.609 & kilometer $(\mathrm{km})$ \\
\hline \multicolumn{3}{c}{ Area } \\
\hline square mile $\left(\mathrm{mi}^{2}\right)$ & 259.0 & hectare $(\mathrm{ha})$ \\
square mile $\left(\mathrm{mi}^{2}\right)$ & 2.590 & square kilometer $\left(\mathrm{km}^{2}\right)$ \\
\hline & Mass & \\
\hline pound per square mile per year $\left[\left(\mathrm{lb} / \mathrm{mi}^{2}\right) \mathrm{yr}\right]$ & 0.001751 & kilogram per hectare per year $[(\mathrm{kg} / \mathrm{ha}) / \mathrm{yr}]$ \\
pound, avoirdupois $(\mathrm{lb})$ & 0.0004536 & metric ton \\
pound, avoirdupois $(\mathrm{lb})$ & 0.4536 & kilogram $(\mathrm{kg})$ \\
\hline
\end{tabular}

\section{Datum}

Horizontal coordinate information is referenced to the North American Datum of 1983 (NAD 83).

\section{Supplemental Information}

Concentrations of chemical constituents in water are given in milligrams per liter (mg/L).

A water year is defined as the 12-month period from October 1 through September 30. The water year is designated by the calendar year in which it ends and which includes 9 of the 12 months. Thus, the year ending September 30, 2010, is called the 2010 water year.

\section{Abbreviations}

$\begin{array}{ll}\text { AMLE } & \text { adjusted maximum likelihood estimation } \\ B_{p} & \text { flux-bias statistic } \\ \text { CCMP } & \text { Comprehensive Conservation and Management Plan } \\ E & \text { Nash-Sutcliffe efficiency index } \\ \text { LIS } & \text { Long Island Sound } \\ \text { LISS } & \text { Long Island Sound Study } \\ \text { LOADEST } & \text { Load Estimator } \\ \text { MLE } & \text { maximum likelihood estimation } \\ \text { NWIS } & \text { National Water Information System } \\ \text { PLR } & \text { partial load ratio } \\ \text { R-LOADEST } & \text { version of LOADEST that runs in R software } \\ \text { TMDL } & \text { total maximum daily load } \\ \text { TN } & \text { total nitrogen } \\ \text { USGS } & \text { U.S. Geological Survey }\end{array}$




\title{
Nitrogen Loads from Selected Rivers in the Long Island Sound Basin, 2005-13, Connecticut and Massachusetts
}

By John R. Mullaney

\begin{abstract}
Total nitrogen loads at 14 water-quality monitoring stations were calculated by using discrete measurements of total nitrogen and continuous streamflow data for the period 2005-13 (water years 2006-13). Total nitrogen loads were calculated by using the LOADEST computer program.

Overall, for water years 2006-13, streamflow in Connecticut was generally above normal. Total nitrogen yields ranged from 1,160 to 23,330 pounds per square mile per year. Total nitrogen loads from the French River at North Grosvenordale and the Still River at Brookfield Center, Connecticut, declined noticeably during the study period. An analysis of the bias in estimated loads indicated unbiased results at all but one station, indicating generally good fit for the LOADEST models.
\end{abstract}

\section{Introduction}

The Long Island Sound Study (LISS) began in 1985 when Congress appropriated funds for the U.S. Environmental Protection Agency (EPA) to carry out a program to research, monitor, and assess the water quality of Long Island Sound (LIS) as part of the National Estuary Program. This work has been undertaken in concert with the States of Connecticut and New York, forming a bistate partnership consisting of Federal and State agencies, user groups, concerned organizations, and individuals dedicated to restoring and protecting LIS.

In 1994, the LISS completed a Comprehensive Conservation and Management Plan (CCMP) that identified problems that merit special attention, including low dissolved oxygen (hypoxia), toxic contamination, pathogen contamination, the effects of habitat degradation and loss on the health of living resources, land use and development resulting in the habitat loss, and degradation of water quality (Long Island Sound Study, 1994). Hypoxia was identified as the highest priority water-quality problem for Long Island Sound. The LISS defined hypoxia as concentrations of dissolved oxygen of 3 milligrams per liter or less in the water column (Long Island Sound Study, 1994). Hypoxia occurs during the summer months in the bottom waters of western Long Island Sound and is believed to be caused by overenrichment of nitrogen.

A total maximum daily load (TMDL) was implemented in 2000 with the goal of reducing the point and nonpoint source nitrogen loads to LIS from New York and Connecticut by 58.5 percent by 2014 (New York State Department of Environmental Conservation/Connecticut Department of Environmental Protection, 2000). In 2010, the LISS formed a five-State committee (including representatives from the States of Connecticut, New York, Massachusetts, New Hampshire, and Vermont) to evaluate progress towards meeting the TMDL goals and to determine revised nitrogen loading targets; in addition, the CCMP was updated and revised in 2014 (Long Island Sound Study, 2014). This effort involved reviewing program progress, soliciting stakeholder and public input, and 
developing a framework for updating this document. Both of these efforts require information on tributary nitrogen loads to LIS in order to track progress toward management goals.

The U.S. Geological Survey (USGS) has been working cooperatively with the Connecticut Department of Energy and Environmental Protection (CTDEEP) to monitor the water quality of streams in Connecticut since the 1970s. Nitrogen loads from tributaries to Long Island Sound have been previously reported by Mullaney and others (2002), Trench and others (2012), and Varekamp and others (2014). In water year 2008 (October 2007), sampling for nutrients was begun at five new water-quality monitoring stations. An analysis of nitrogen loads for these stations and others that were sampled for water years 1999-2009 was published by Mullaney and Schwarz (2013). In addition to these five stations, data collection has been ongoing at nine additional stations. These nine stations typically have less than 200 observations of water quality and therefore were not suitable for analysis by the Weighted Regressions on Time, Discharge, and Season (WRTDS) method (Hirsch and others, 2010) that is being done concurrently using data from other long-term stations with more than 20 years of data and greater than 200 water-quality measurements.

This report includes information on the nitrogen loads from 14 water-quality monitoring stations with data from water years 2006-13 (fig. 1; table 1). Stations in the analysis contained in this report typically had less than 200 observations of water quality from less than a 10-year time period and therefore were analyzed by using a method developed by Runkel and others (2004), which has been used in many previous USGS studies and is appropriate for use with short data records. This report is a continuation of an analysis done by Mullaney and Schwarz (2013) and Mullaney (2013), which supplements work done to analyze flow-normalized trends in concentrations and loads at long-term stations (Mullaney, 2015).

\section{Methods}

The methods for this study included the collection of water-quality samples and retrieval of water-quality and river discharge information for each station from the USGS National Water Information System. The field sampling procedures are described by Mullaney and Schwarz (2013), and the laboratory methods are detailed in Mullaney (2013).

Estimates of total nitrogen (TN) loads were calculated for monitoring stations (table 1) by using water-quality and streamflow data that were available in the USGS National Water Information System (NWIS) collected for water years 2006 through 2013. Total nitrogen data (parameter code 00600), which were retrieved directly from NWIS, were calculated as the sum of total ammonia plus organic nitrogen (USGS parameter code 00625) and nitrite plus nitrate nitrogen (USGS parameter code 00631).

The annual loads of TN were calculated for the monitoring stations by using the Load Estimator (LOADEST) computer program (Runkel and others, 2004). Given a time series of daily streamflow and instantaneous constituent concentration, LOADEST assists the user in developing a regression model for the estimation of constituent load (flux). LOADEST regression models from Runkel and others (2004) that were used in this study are listed in appendix 1. Explanatory variables in the regression model may include various functions of streamflow, decimal time, seasonal terms, and additional userspecified data. The formulated regression model then is used to estimate loads over a user-specified time interval.

Load estimations for this project used adjusted maximum likelihood estimation (AMLE; Cohn, 1988; Cohn and others, 1992) because some of the datasets contain censored data (below an analytical or reporting threshold). Retransformation bias (underestimation of true loads resulting from changing estimates made in log space back to actual numbers) is handled in the AMLE by equations specially designed for censored data. Load estimations using datasets with no censored data converge to the 
maximum likelihood estimation (MLE). Either estimation method, used appropriately, results in a minimum-variance, unbiased estimate of constituent loads (Runkel and others, 2004). Estimations using the AMLE or MLE require that model residuals are normally distributed. As part of the evaluation of models, plots of residuals were analyzed graphically to verify that residuals met or nearly met normality assumptions.

The calculations in this report were done by using a version of LOADEST adapted to the R statistical package (U.S. Geological Survey, 2015a). The models were run by using the command "SelBestModel," which selects the "best” predefined rating-curve (regression) model for river load estimation. The selected models are listed in table 2.

One additional feature of R-LOADEST is that it calculates several measures of bias diagnostics as described by Runkel (2013). The updates to LOADEST were done because regression methods for load estimation can produce results with large positive or negative biases when the selected regression model is a poor representation of the relation between load and the explanatory variables (Stenback and others, 2011). According to Hirsch (2014),

"These large biases arise for one or more of the following reasons: (1) there is a severe lack of fit in terms of the $\ln$ (concentration) vs. In(discharge) relationship, (2) this relationship has a substantially different shape in different seasons of the years, and (3) the errors from the fitted model are severely heteroscedastic.”

The computer program LOADEST outputs three diagnostics related to flux bias, including the flux-bias statistic $\left(B_{p}\right)$, the partial load ratio $(P L R)$, and the Nash-Sutcliffe efficiency index $(E)$ (Runkel, 2013). The $B_{p}$, expressed in percent, is defined as [mean(predicted flux) - mean(observed flux)] / mean(observed flux). A $B_{p}$ of zero indicates an unbiased model (Runkel, 2013). The LOADEST models are generally considered biased when the magnitude of $B_{p}$ exceeds 25 percent (Runkel, 2013); Hirsch and De Ciccio (2014) and Hirsch (2014) indicate $B_{p}$ should be within plus or minus 10 percent, and additional model variables might be needed for correction of the loads if $B_{p}$ is greater than 10 percent. A PLR of 1 is considered an unbiased model, whereas a value greater than 1 or less than 1 indicates positive and negative bias, respectively, The Nash-Sutcliffe efficiency index extends the comparison of observed and estimated loads using the mean of the observed loads. Values of $E$ range from negative infinity to 1.0, with a value of 1.0 indicating a perfect fit, and a value of 0 indicating that the load estimates are only as accurate as the mean. Values of $E$ less than 0 indicate that the observed mean is a better estimate of load than the selected regression model (Runkel, 2013). The flux-bias diagnostics for each site are presented in table 2.

\section{Loads of Total Nitrogen}

Loads of TN using R-LOADEST were calculated at the 14 water-quality monitoring stations listed in table 1 with available data for water years 2006-13. Results of the analyses are summarized in figure 2 and table 2. Results include the daily and annual loads, annual lower and upper limits of the 95percent confidence interval of load for TN, and the annual TN yield (annual load divided by the drainage basin area). Streamflow in Connecticut, which is an important determinant in annual variability in constituent loads, typically was greater than or near the median for water years 1984-2013. Streamflow in Connecticut in water years 2006 and 2011 was among the highest between 1901 and 2013 (U.S. Geological Survey, 2015b).

Annual TN yields at most monitoring stations were less than 5,000 pounds per square mile (lb/mi $\left.{ }^{2}\right)$ in most years. Stations with the lowest yields included Oil Mill Brook (011277914), a small headwater tributary, and the Natchaug (01120800) and Indian Rivers (01195100) (fig. 1; table 1), 
both dominantly forested basins (Mullaney and Schwarz, 2013). Stations with the highest yields included Broad Brook (01184490), an agricultural basin; Still River (01201487), a wastewater-receiving stream; and Sasco Brook (01208950), an urbanized coastal basin (Mullaney and Schwarz, 2013). Overall, annual TN yields ranged from 1,160 lb/mi ${ }^{2}$ at Oil Mill Brook (011277914) to 23,300 lb/mi $/ \mathrm{mr}^{2}$ at Broad Brook (01184490) (fig. 3). Annual loads and yields were variable with no apparent trends at most stations; however, two stations had apparent downward trends in TN yield and load: the French River (01125100; fig. 2D) and the Still River (01201487, fig. 2L). These changes likely represent reductions in TN loads from wastewater-treatment facilities. Whereas data for the wastewater-treatment facilities upstream from the French River are not readily available, the Danbury wastewater-treatment facility in the Still River Basin has reduced average daily TN loads from 2,072 pounds per day (lb/d) in calendar year 2006 to $401 \mathrm{lb} / \mathrm{d}$ in calendar year 2013 as a result of upgrades to the facility to meet current wasteload allocations (Connecticut Department of Energy and Environmental Protection, 2014).

Statistical measures indicated that nearly all of the R-LOADEST models were within acceptable limits. The $B_{p}$ was less than 10 percent, and $P L R$ and $E$ were near 1.0 for nearly all sites. The $B_{p}$ was high for the Natchaug River (station 01120800) with a negative bias of -11.6 percent; however, concentrations and yields of $\mathrm{TN}$ at this station were among the lowest measured for this study.

\section{Summary}

The U.S. Geological Survey, in cooperation with the Connecticut Department of Energy and Environmental Protection, has been monitoring the total nitrogen (TN) concentrations and streamflows at major and minor tributaries of Long Island Sound since the 1970s. Data from 14 water-quality monitoring stations for water years 2006-13 were analyzed by using R-LOADEST to provide an update on TN loads at these sites.

The R-LOADEST regressions were developed for each station by using input data that included periodic measurements of nutrients and mean daily streamflow. These models, which were automatically selected in the R-LOADEST software, were used to calculate annual loads of TN. Three flux-bias diagnostics were calculated to assess model fit to the data for each monitoring station.

During water years 2006-13, streamflows were generally above normal in Connecticut. Annual yields of TN from the 14 stations ranged from 1,160 to 23,300 pounds per square mile per year. Two sites (French River, 01125100; Still River, 01201487) had visible downward trends in TN load during water years 2006-13. The flux-bias statistical measures were satisfactory at 13 of the 14 stations; one station on the Natchaug River (01120800) had a negative flux bias of -11.6 percent.

\section{References Cited}

Cohn, T.A., 1988, Adjusted maximum likelihood estimation of the moments of lognormal populations from type I censored samples: U.S. Geological Survey Open-File Report 88-350, 34 p.

Cohn, T.A., Gilroy, E.J., and Baier, W.G., 1992, Estimating fluvial transport of trace constituents using a regression model with data subject to censoring, in Proceedings of the Section on Statistics and the Environment, joint statistical meeting, Boston, August 9-13, 1992: Alexandria, Va., American Statistical Association, p. 142-151.

Connecticut Department of Energy and Environmental Protection, 2014, Report of the Nitrogen Credit Advisory Board for calendar year 2013 to the Joint Standing Environment Committee of the General Assembly: Hartford, Conn., Connecticut Department of Energy and Environmental Protection, 48 p., accessed October 21, 2015, at http://www.ct.gov/deep/lib/deep/water/municipal_wastewater/nitrogen_report_2013.pdf. 
Hirsch, R.M., 2014, Large biases in regression-based constituent flux estimates - Causes and diagnostic tools: Journal of the American Water Resources Association, v. 50, no. 6, p. 1401-1424.

Hirsch, R.M., and De Cicco, Laura, 2014, User guide to Exploration and Graphics for RivEr Trends (EGRET) and dataRetrieval—R packages for hydrologic data: U.S. Geological Survey Techniques and Methods, book 4, chap. A10, 94 p., accessed July 28, 2015, at http://dx.doi.org/10.3133/tm4A10. Hirsch, R.M., Moyer, D.L., and Archfield, S.A., 2010, Weighted Regressions on Time, Discharge, and Season (WRTDS), with an application to Chesapeake Bay river inputs: Journal of the American Water Resources Association, v. 46, no. 5, p. 857-880.

Long Island Sound Study, 1994, The comprehensive conservation and management plan-March 1994: Long Island Sound Study, 168 p., appendixes, accessed April 15, 2015, at http://longislandsoundstudy.net/wp-content/uploads/2011/10/management_plan.pdf.

Long Island Sound Study, 2014, Draft comprehensive conservation and management plan updateInvesting in a regional asset: Long Island Sound Comprehensive Conservation and Management Plan, 79 p., accessed April 15, 2015, at http://longislandsoundstudy.net/wp-content/uploads/2014/09/DraftLISS-CCMP-final-9_8_14SM_Corrected.pdf.

Mullaney, J.R., 2016, Nutrient, organic carbon and chloride concentrations and loads in selected Long Island Sound tributaries-Four decades of change following the passing of the Federal Clean Water Act: U.S. Geological Survey Scientific Investigations Report 2015-5189, 47 p., http://dx.doi.org/10.3133/sir20155189.

Mullaney, J.R., 2013, Nutrient concentrations and loads and Escherichia coli densities in tributaries of the Niantic River estuary, southeastern Connecticut, 2005 and 2008-2011: U.S. Geological Survey Scientific Investigations Report 2013-5008, 27 p., accessed December 7, 2015, at http://pubs.usgs.gov/sir/2013/5008/.

Mullaney, J.R., and Schwarz, G.E., 2013, Estimated nitrogen loads from selected tributaries in Connecticut draining to Long Island Sound, 1999-2009: U.S. Geological Survey Scientific Investigations Report 2013-5171, 65 p., accessed December 7, 2015, at http://pubs.er.usgs.gov/publication/sir20135171.

Mullaney, J.R., Schwarz, G.E., and Trench, E.C.T., 2002, Estimation of nitrogen yields and loads from basins draining to Long Island Sound, 1988-98: U.S. Geological Survey Water-Resources Investigations Report 02-4044, 84 p. [Also available at https://pubs.er.usgs.gov/publication/wri024044.]

New York State Department of Environmental Conservation/Connecticut Department of Environmental Protection, 2000, A total maximum daily load analysis to achieve water-quality standards for dissolved oxygen in Long Island Sound: Albany, N.Y., and Hartford, Conn., 73 p.

Runkel, R.L., 2013, Revisions to LOADEST, April 2013: U.S. Geological Survey documentation, 6 p., accessed April 17, 2015, at http://water.usgs.gov/software/loadest/doc/loadest_update.pdf.

Runkel, R.L., Crawford, C.G., and Cohn, T.A., 2004, Load estimator (LOADEST)—A Fortran program for estimating constituent loads in streams and rivers: U.S. Geological Survey Techniques and Methods book 4, chap. A5, 69 p., accessed December 7, 2015, at http://pubs.usgs.gov/tm/2005/tm4A5/.

Stenback, G.A., Crumpton, W.G., Schilling, K.E., and Helmers, M.J., 2011, Rating curve estimation of nutrient loads in Iowa rivers: Journal of Hydrology, v. 396, p. 158-169.

Trench, E.C.T., Moore, R.B., Ahearn, E.A., Mullaney, J.R., Hickman, R.E., and Schwarz, G.E., 2012, Nutrient concentrations and loads in the Northeastern United States-Status and trends, 1975-2003: U.S. Geological Survey Scientific Investigations Report 2011-5114, 169 p. [Also available at http://pubs.usgs.gov/sir/2011/5114.] 
U.S. Geological Survey, 2015a, USGS water science R functions for LOAD ESTimation of constituents in rivers and streams: U.S. Geological Survey R statistical package, accessed December 7, 2015, at https://github.com/USGS-R/rloadest.

U.S. Geological Survey, 2015b, Table of computed runoff by water-year for Connecticut: U.S. Geological Survey WaterWatch, accessed October 23, 2015, at http://waterwatch.usgs.gov/index.php?r=ct\&id=statesum.

Varekamp, J.C., McElroy, A.E., Mullaney, J.R., and Breslin, V.T., 2014, Metals, organic compounds, and nutrients in Long Island Sound-Sources, magnitudes, trends, and impacts, in Latimer, J.S., Tedesco, M.A., Swanson, R.L., Yarish, C., Stacey, P., and Garza, C., eds., Long Island SoundProspects for the urban sea: New York, Springer, p. 203-283. 


\section{Figures}

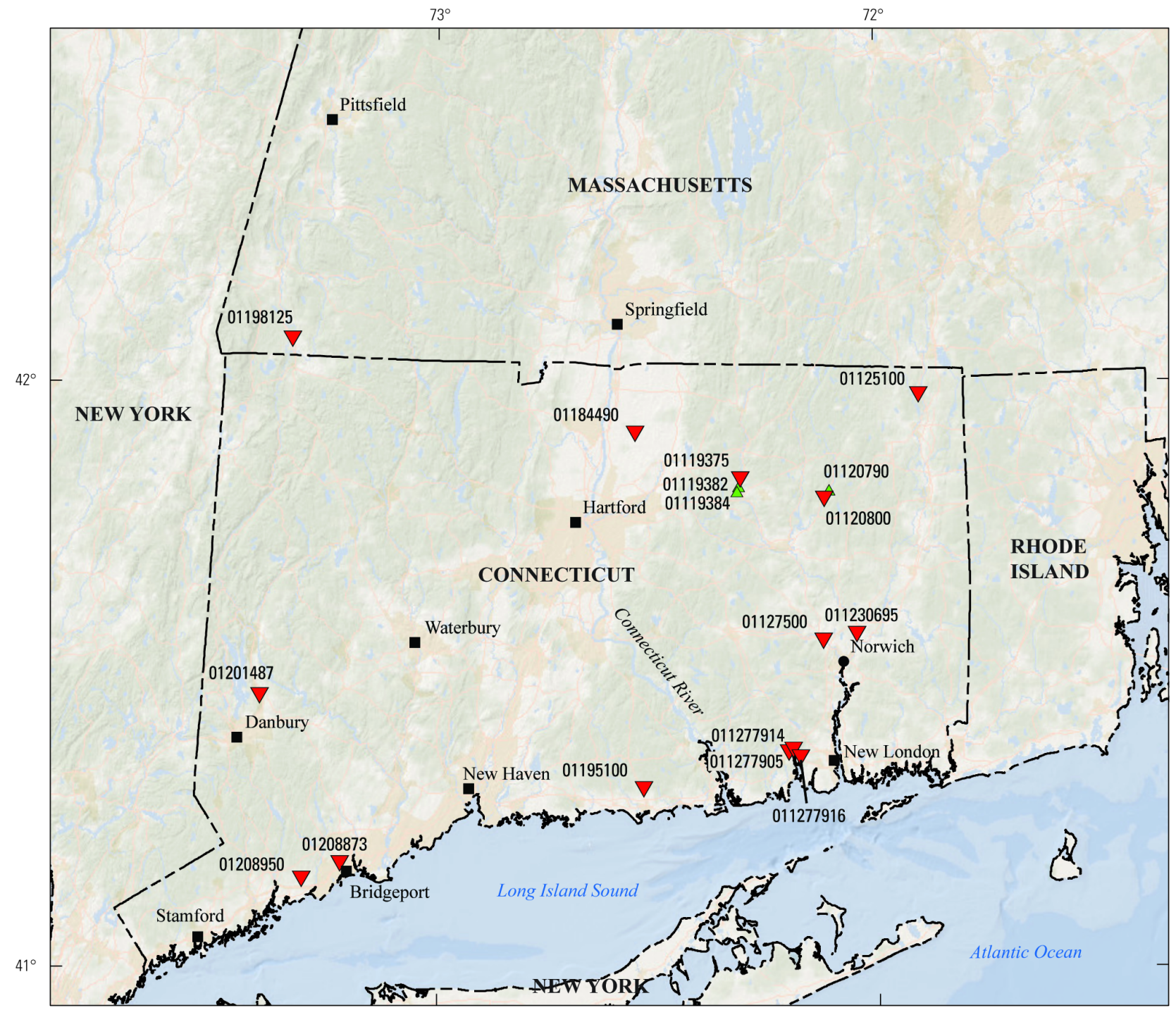

Base from Esri Inc. World Ocean Base, 2014, 1:72,000
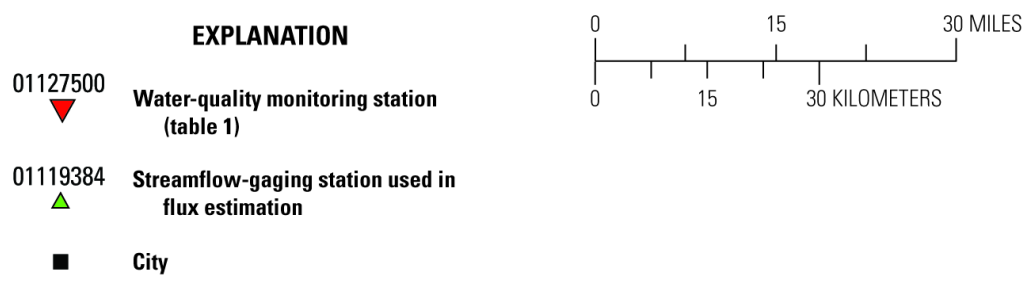

Figure 1. Selected water-quality monitoring and streamflow-gaging stations, Long Island Sound Basin, Connecticut and Massachusetts. 

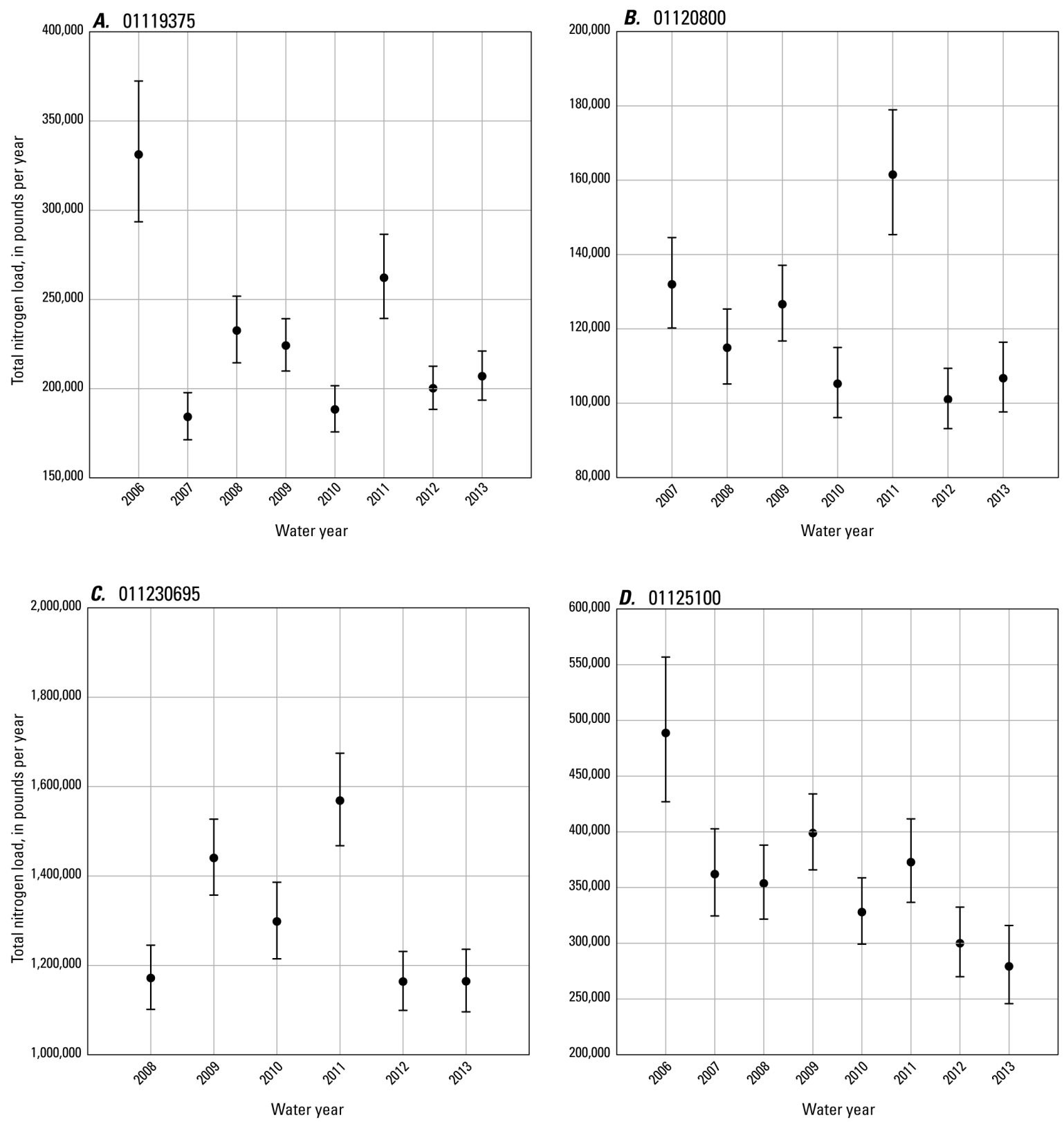

EXPLANATION

Upper limit of the 95-percent confidence interval
Load estimate
Lower limit of the 95-percent confidence interval

Figure 2. Total nitrogen load estimate and limit of the 95-percent confidence interval for U.S. Geological Survey (USGS) water-quality monitoring stations $A, 01119375$, water years 2006-13; $B, 01120800$, water years 2007-13; $C, 011230695$, water years 2008-13; $D, 01125100$, water years 2006-13, $E ; 01127500$, water years 2008-13; $F$, 011277905, water years 2009-12; G, 011277914, water years 2009-12; H, 011277916, water years 2009-12; I, 01184490; water years 2006-13; J, 01195100, water years 2008-13; $K, 01198125$, water years 2008-13; $L$, 01201487, water years 2006-13; M, 01208873, water years 2008-13, and N, 01208950, water years 2008-13. Number shown is USGS station identification number found in figure 1 and table 1; bars extend across the 95percent confidence interval. 

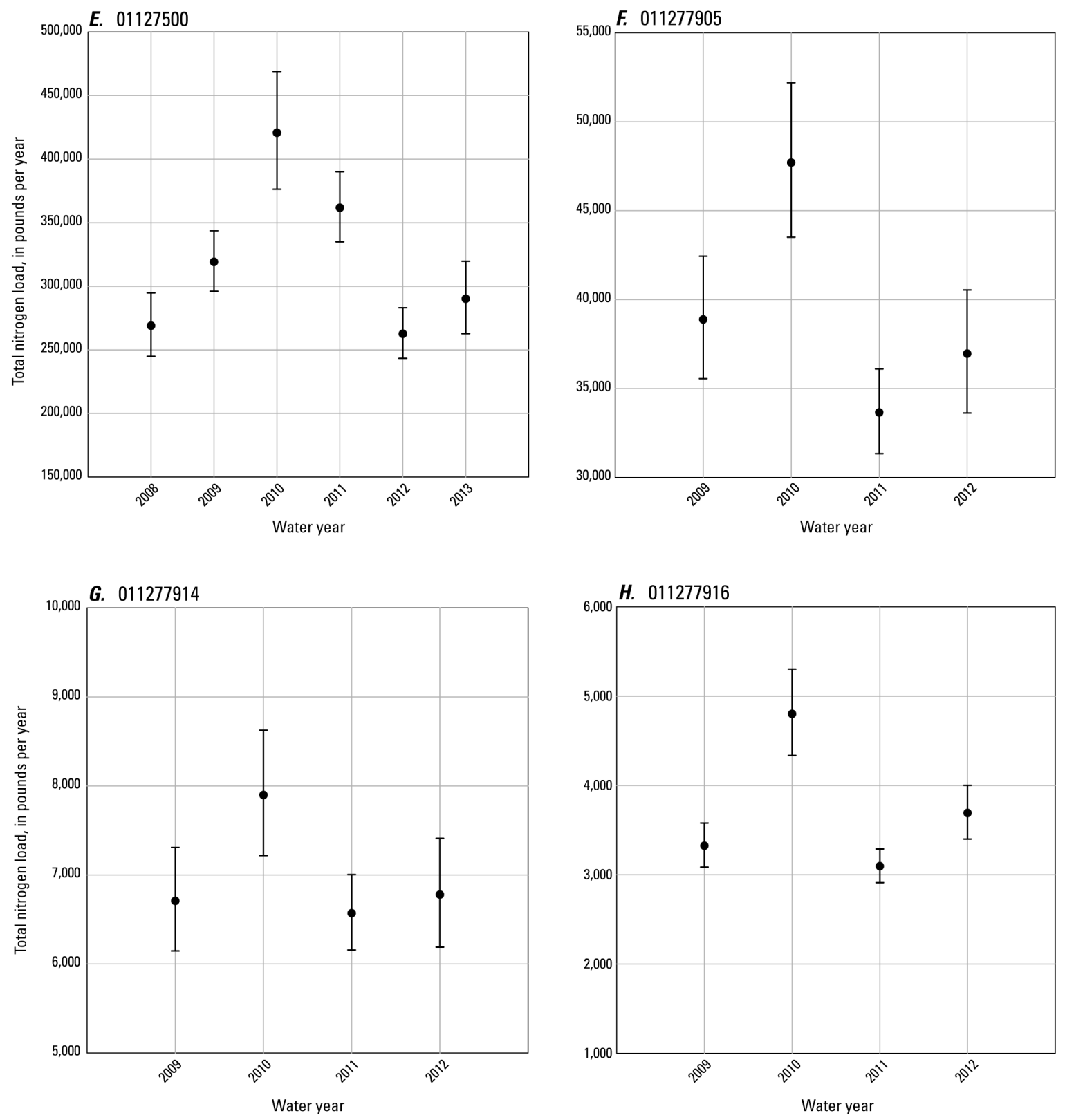

EXPLANATION

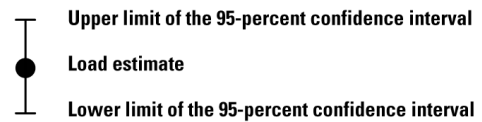

Figure 2. Total nitrogen load estimate and limit of the 95-percent confidence interval for U.S. Geological Survey (USGS) water-quality monitoring stations $A, 01119375$, water years 2006-13; $B, 01120800$, water years 2007-13; $C, 011230695$, water years 2008-13; $D, 01125100$, water years 2006-13, $E ; 01127500$, water years 2008-13; $F$, 011277905, water years 2009-12; G, 011277914, water years 2009-12; H, 011277916, water years 2009-12; I, 01184490; water years 2006-13; J, 01195100, water years 2008-13; K, 01198125, water years 2008-13; $L$, 01201487, water years 2006-13; M, 01208873, water years 2008-13, and N, 01208950, water years 2008-13. Number shown is USGS station identification number found in figure 1 and table 1; bars extend across the 95percent confidence interval._Continued 

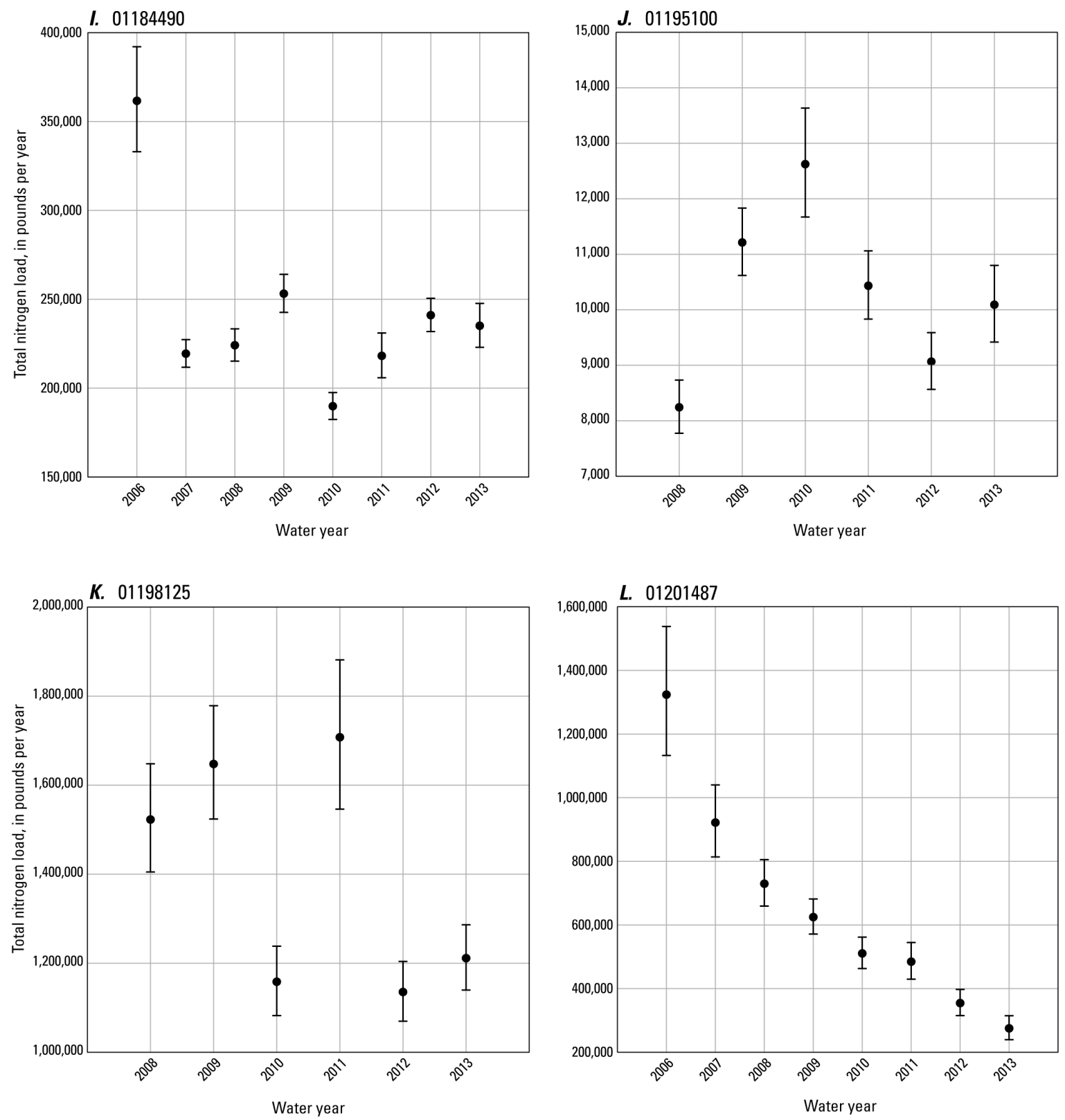

EXPLANATION

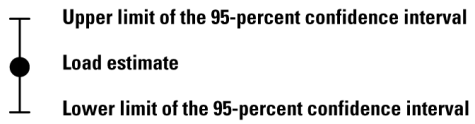

Figure 2. Total nitrogen load estimate and limit of the 95-percent confidence interval for U.S. Geological Survey (USGS) water-quality monitoring stations $A, 01119375$, water years 2006-13; B, 01120800, water years 2007-13; $C, 011230695$, water years 2008-13; $D, 01125100$, water years 2006-13, $E ; 01127500$, water years 2008-13; $F$, 011277905, water years 2009-12; G, 011277914, water years 2009-12; H, 011277916, water years 2009-12; I, 01184490; water years 2006-13; J, 01195100, water years 2008-13; K, 01198125, water years 2008-13; $L$, 01201487, water years 2006-13; M, 01208873, water years 2008-13, and N, 01208950, water years 2008-13. Number shown is USGS station identification number found in figure 1 and table 1; bars extend across the 95percent confidence interval._-Continued 

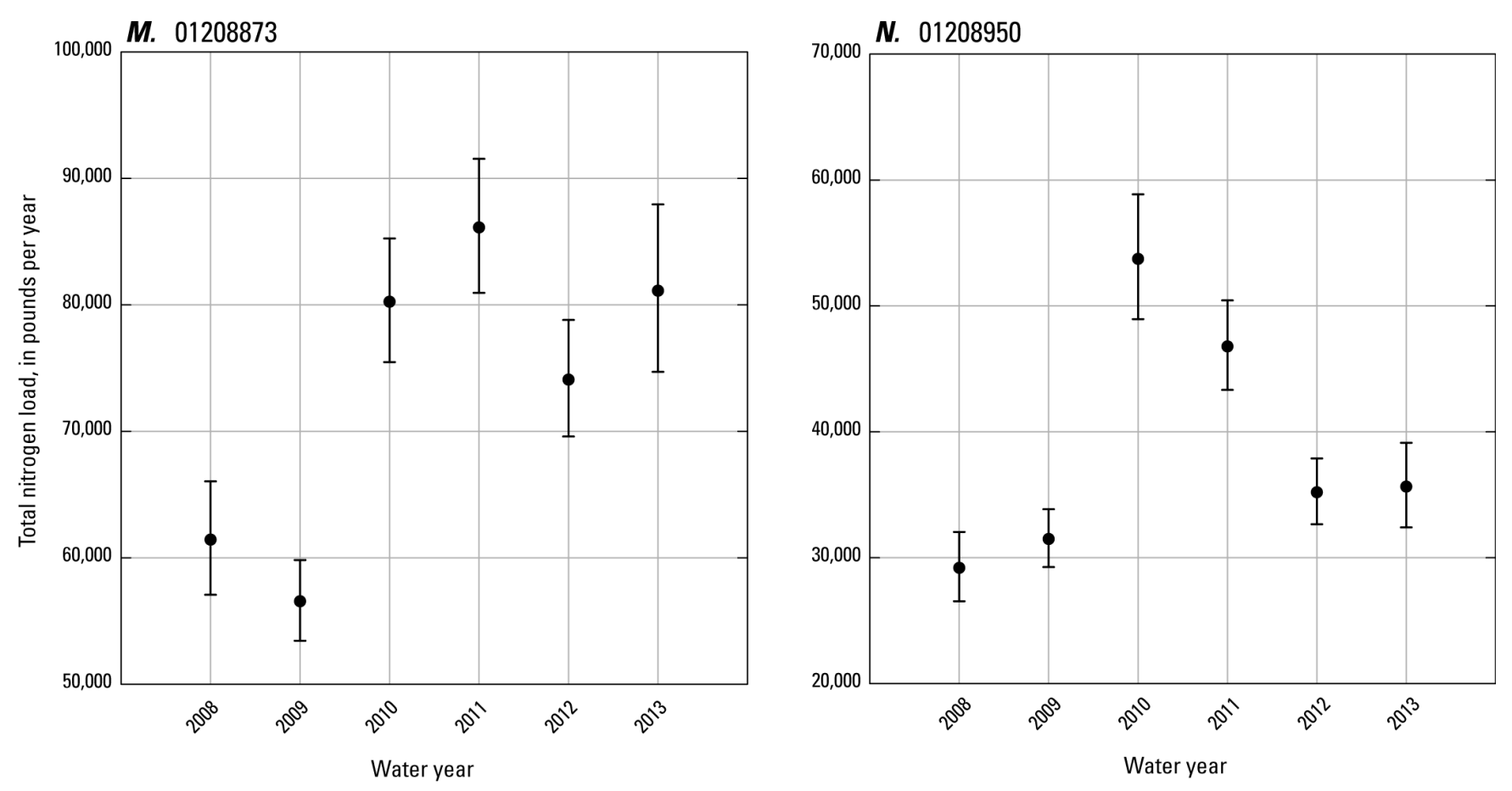

\section{EXPLANATION}

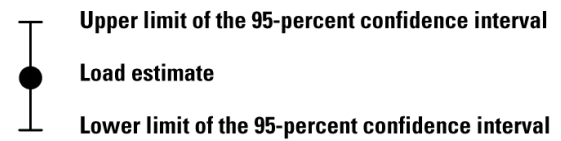

Figure 2. Total nitrogen load estimate and limit of the 95-percent confidence interval for U.S. Geological Survey (USGS) water-quality monitoring stations $A, 01119375$, water years 2006-13; $B, 01120800$, water years 2007-13; $C$, 011230695, water years 2008-13; $D, 01125100$, water years 2006-13, $E ; 01127500$, water years 2008-13; $F$, 011277905, water years 2009-12; G, 011277914, water years 2009-12; H, 011277916, water years 2009-12; I, 01184490; water years 2006-13; J, 01195100, water years 2008-13; $K, 01198125$, water years 2008-13; $L$, 01201487, water years 2006-13; $M, 01208873$, water years 2008-13, and $N, 01208950$, water years 2008-13. Number shown is USGS station identification number found in figure 1 and table 1; bars extend across the 95percent confidence interval.-Continued 


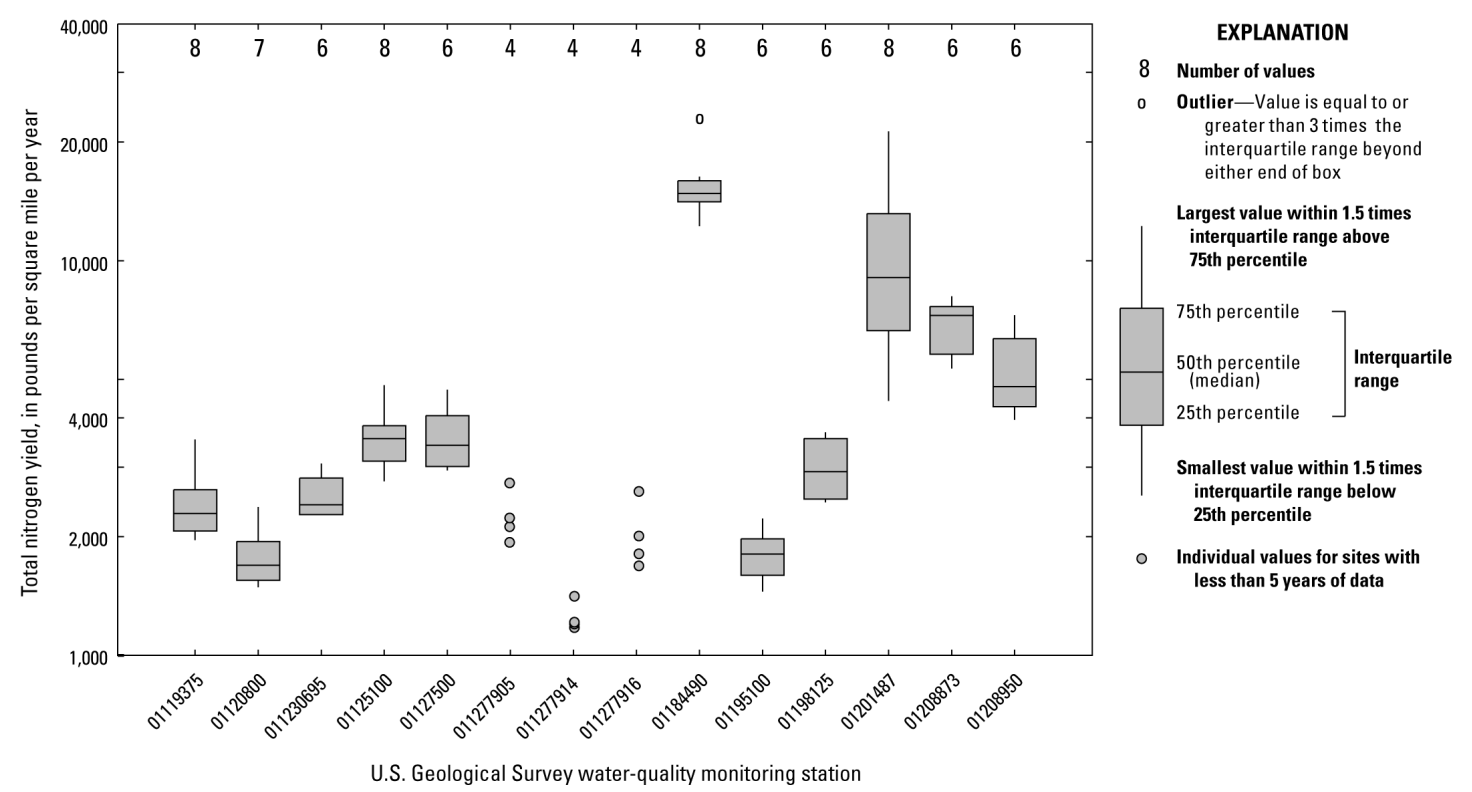

Figure 3. Total nitrogen yield for U.S. Geological Survey water-quality monitoring stations in the Long Island Sound Basin, Connecticut and Massachusetts, water years 2006-13. Station locations are shown in figure 1, and station names are listed in table 1. 


\section{Tables}

Table 1. Water-quality monitoring stations used for nitrogen load analysis from rivers draining to Long Island Sound Basin.

[USGS, U.S. Geological Survey; ID, identification number; Conn., Connecticut; N, north; Rd., Road; Rte., Route; Mass., Massachusetts]

\begin{tabular}{llc}
\hline \multicolumn{1}{c}{ USGS station ID } & \multicolumn{1}{c}{ Station name } & Drainage area, in square miles \\
\hline $01119375^{1}$ & Willimantic River at Merrow, Conn. & 94. \\
011230695 & Shetucket River at Taftville, Conn. & 512. \\
$01120800^{2}$ & Natchaug River at Chaplin, Conn. & 67.9 \\
01125100 & French River at North Grosvenordale, Conn. & 101. \\
01127500 & Yantic River at Yantic, Conn. & 89.3 \\
011277905 & Latimer Brook near I-95 N Exit 75 near Flanders, Conn. & 17.6 \\
011277914 & Oil Mill Brook at Gurley Rd. near East Lyme, Conn. & 5.67 \\
011277916 & Stony Brook at Rte. 1 near Flanders, Conn. & 1.86 \\
01184490 & Broad Brook at Broad Brook, Conn. & 15.5 \\
01195100 & Indian River near Clinton, Conn. & 5.68 \\
01198125 & Housatonic River near Ashley Falls, Mass. & 465. \\
01201487 & Still River at Route 7 at Brookfield Center, Conn. & 62.3 \\
01208873 & Rooster River at Fairfield, Conn. & 10.6 \\
01208950 & Sasco Brook near Southport, Conn. & 7.38 \\
\hline
\end{tabular}

${ }^{1}$ Flow information for this station from station $01119384 \times 0.96$ (drainage area correction) for water years 2006-08, and station $01119382 \times 0.98$ (drainage area correction) for water years 2009-13.

${ }^{2}$ Flow information for this station from station $01120790 \times 1.02$ (drainage area correction).

Table 2. Total nitrogen load and yield and selected regression model and flux-bias diagnostics for each waterquality monitoring station, Long Island Sound Basin, water years 2006-13.

[Available for download at http://dx.doi.org/10.3133/ofr20161007.] 


\section{Appendix 1. LOADEST Regression Equations Used To Estimate Annual Loads of Total Nitrogen From Selected Rivers in the Long Island Sound Basin, 2005-13, Connecticut and Massachusetts}

Table 1-1. LOADEST regression models used in this study.

[Modified from Runkel and others (2004, table 7). $a$, model coefficient; $\ln Q=\ln$ (streamflow) - center of $\ln ($ streamflow); dtime $=$ decimal time - center of decimal time]

Model number

Regression model

\begin{tabular}{ll}
\hline 1 & $a_{0}+a_{1} \ln Q$ \\
2 & $a_{0}+a_{1} \ln Q+a_{2} \ln Q^{2}$ \\
3 & $a_{0}+a_{1} \ln Q+a_{2} d t i m e$ \\
4 & $a_{0}+a_{1} \ln Q+a_{2} \sin (2 \pi d t i m e)+a_{3} \cos (2 \pi d t i m e)$ \\
5 & $a_{0}+a_{1} \ln Q+a_{2} \ln Q^{2}+a_{3} d t i m e$ \\
6 & $a_{0}+a_{1} \ln Q+a_{2} \ln Q^{2}+a_{3} \sin (2 \pi d t i m e)+a_{4} \cos (2 \pi d t i m e)$ \\
7 & $a_{0}+a_{1} \ln Q+a_{2} \sin (2 \pi d t i m e)+a_{3} \cos (2 \pi d t i m e)+a_{4} d t i m e$ \\
8 & $a_{0}+a_{1} \ln Q+a_{2} \ln Q^{2}+a_{3} \sin (2 \pi d t i m e)+a_{4} \cos (2 \pi d t i m e)+a_{5}$ dtime \\
9 & $a_{0}+a_{1} \ln Q+a_{2} \ln Q^{2}+a_{3} \sin (2 \pi d t i m e)+a_{4} \cos (2 \pi d t i m e)+a_{5}$ dtime $+a_{6}$ dtime \\
\hline
\end{tabular}


For more information concerning this report, contact: Director, New England Water Science Center

\section{U.S. Geological Survey}

101 Pitkin Street

East Hartford, CT 06108

dc_nweng@usgs.gov

or visit our Web site at:

http://newengland.water.usgs.gov

Publishing support by:

The Pembroke and Lafayette Publishing Service Centers. 
